Review Article

\title{
A STUDY ON ASSESSM ENT OF KNOWLEDGE ON PRACTICE REGARDING FIRST AID MEASURES AM ONG THE SELF HELP GROUPS IN SELECTED AREAS OF MANGALORE WITH A VIEW TO DEVELOP INFORM ATION MODULE
}

\author{
Deepak M. ${ }^{1}$, Sabitha Nayak ${ }^{2}$, \\ ${ }^{1} 2^{\text {nd }}$ year M Sc Nursing student, ${ }^{2}$ Prof. \& Vice Principal, Department of Obstetrics and Gynecological Nursing, \\ Nitte Usha Institute of Nursing Sciences, Nitte University, Deralakatte, M angalore - 575018. \\ Correspondence : \\ Deepak M. \\ Department of Obstetrics and Gynecological Nursing, \\ Nitte Usha Institute of Nursing Sciences, Nitte University, Deralakatte, M angalore - 575018.
}

\begin{abstract}
:
A descriptive study was conducted to assess the knowledge on first aid measures among self help group members. The study was conducted in selected community areas of Natekal PHC. The sample for the study comprised of 100 self help group members selected by purposive sampling technique. The data was collected between $2^{\text {nd }}$ October 2011 and $13^{\text {th }}$ November 2011 by using structured questionnaires. The data was analyzed using descriptive and inferential statistics. The study finding revealed that majority of the samples $55 \%$ were in the age group of $25-30$ years, $64 \%$ were females, $44 \%$ of them were manual laborers and $39 \%$ received information from the teaching programs, $20 \%$ from mass media $13 \%$ from friends and $17 \%$ of them do not have exposure to any source of information about the first aid practices. The results showed that majority of the samples $62 \%$ had good knowledge, and $38 \%$ had average knowledge about the first aid practice. Among the seven areas of the knowledge assessment on first aid measures the mean percentage score of the samples were highest (70\%) in the area of poisoning and lowest score $(28.8 \%)$ in the area of bleeding. There is no significant association between knowledge and selected demographic variables like age, educational status, membership in any social organization, occupation, place of living, and source of information other than gender.
\end{abstract}

Keywords: Knowledge; self help group members; first aid

\section{Introduction :}

Long ago, Henry Sigerist, the medical historian stated that "the people's health ought to be the concern of the people themselves. They must struggle for it and plan for it. The war against disease and for health cannot be fought by physicians alone. It is a people's war in which the entire population must be mobilized permanently". ${ }^{1}$ M any times, death results because of delay in reaching the casualty to appropriate medical care, and/or lack of knowledge regarding treatment. On

Access this article online Quick Response Code

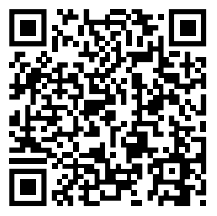
the contrary, if help is provided to casualty as soon as possible following the accident or injury, a life could be saved. This helps lower mortality and morbidity rates, complications due to injury or delay in the treatment and a lesser monetary burden on the casualty. Administration of first aid must not delay activation of the emergency medical services system or other medical assistance when required. ${ }^{1}$

It is a common occurrence that whenever an accident takes place or any person gets injured, people around the casualty usually panic more than the casualty himself. This should not be the case. The First Aider should have a positive attitude and be prepared to help the casualty. The First Aider should also have adequate knowledge and skills about what he is doing, and be encouraging and reassuring to the victims. Besides learning First Aid, it is the sacred duty of each First Aider to publicize the movement till every citizen of the country learns the methods of First Aid.

Laypersons are important people for saving lives in 
emergency situations. Life-Supporting First-Aid should be part of basic health education and all persons from the age of 10 yrs should learn Life-Supporting First-Aid -skills including Basic Life-Support and cardiopulmonary resuscitation. An important barrier and main concern of laypersons about giving first aid to acutely ill or injured people is the fear of making mistakes. Everyone has the potential to save lives. First aid education and practice are essential tools for saving the lives in emergencies. First aid is an act of humanity showing willingness to save lives with full respect for diversity and without discrimination. Building skills in first aid with the vulnerable people can help to build safer and healthier communities.

The studies related to the first aid showed that consciously and timely first aid applications lowered mortality rates significantly. Fifteen to eighteen percent of deaths as a result of injuries can be prevented by consciously applied first aid practices. For instance, it was reported that giving the patient right position could lower mortality rate as much as $10 \% .{ }^{2}$ In addition to life saving results of first aid, effective and timely first aid practices also prevent the disabilities. For these reasons whole community should be trained in a way that everybody can practice first aid.

\section{Methods:}

A typical descriptive research design was selected in this study. The study was conducted in selected community areas of Natekal PHC. The sample for the study comprised of 100 self help group members. Sample was selected by purposive sampling technique. The data was collected between $2^{\text {nd }}$ October 2011 and $13^{\text {th }}$ November 2011. Structured questionnaires were used for the data collection. The data was analyzed using descriptive and inferential statistics.

\section{Results:}

$M$ ain findings are discussed under the following headings

Section 1: Description of Sample According To Demographic Characteristics

The study finding revealed that $55 \%$ of the samples were in the age group of $\quad 25-30$ years, $64 \%$ were females, $44 \%$ were manual laborers and $39 \%$ received information from the teaching programs, $20 \%$ from mass media $13 \%$ from friends and $17 \%$ do not have exposure to any source of information about the first aid practices

\begin{tabular}{|c|c|c|}
\hline SL.NO & Sample characteristics & Frequency \\
\hline 1. & $\begin{array}{l}\text { Age (yrs) } \\
\begin{array}{l}\text { 1. } 25-30 \\
\text { 2. } 31-40 \\
\text { 3. } 41-50 \\
\text { 4. } 51-60\end{array}\end{array}$ & $\begin{array}{c}55 \\
22 \\
15 \\
8\end{array}$ \\
\hline 2. & $\begin{array}{l}\text { Gender } \\
\text { 1. Male } \\
\text { 2. Female }\end{array}$ & $\begin{array}{l}36 \\
64\end{array}$ \\
\hline 3. & $\begin{array}{l}\text { Educational status } \\
\text { 1. Illiterate } \\
\text { 2. Primary } \\
\text { 3. High school } \\
\text { 4. Graduate }\end{array}$ & $\begin{array}{c}0 \\
52 \\
33 \\
15\end{array}$ \\
\hline 4. & $\begin{array}{l}\text { M ember of any social organization } \\
\text { 1. Yes } \\
\text { 2. No }\end{array}$ & $\begin{array}{c}85 \\
15\end{array}$ \\
\hline 5. & $\begin{array}{l}\text { Occupation } \\
\text { 1. Laborer } \\
\text { 2. Private } \\
\text { 3. Government } \\
\text { 4. Unemployed }\end{array}$ & $\begin{array}{c}44 \\
37 \\
4 \\
15\end{array}$ \\
\hline 6. & $\begin{array}{l}\text { Livesin } \\
\text { 1. Own house } \\
\text { 2. Rented house }\end{array}$ & $\begin{array}{l}83 \\
17\end{array}$ \\
\hline 7. & $\begin{array}{l}\text { Source of information about first aid } \\
\text { 1. No source } \\
\text { 2. Friends } \\
\text { 3. Mass media } \\
\text { 4. Teaching program } \\
\text { 5. Health persons }\end{array}$ & $\begin{array}{l}17 \\
13 \\
20 \\
39 \\
11\end{array}$ \\
\hline
\end{tabular}

Section 2: Assessment of Knowledge of Self Help Group Members Regarding First Aid Practice

\begin{tabular}{|l|c|c|}
\hline Knowledge score & Frequency & Percent \\
\hline Poor & 0 & 0 \\
\hline Average & 38 & 38 \\
\hline Good & 62 & 62 \\
\hline Excellent & 0 & 0 \\
\hline
\end{tabular}


Assessment of mean percentage knowledge of self help group members regarding first aid practice (Area wise)

\begin{tabular}{|l|c|l|l|l|}
\hline Area & $\begin{array}{c}\text { Max. possible } \\
\text { score }\end{array}$ & M ean & S.D & $\begin{array}{l}\text { Percentage } \\
\text { mean }\end{array}$ \\
\hline General & 5 & 3.21 & 1.165 & 64.2 \\
\hline Choking & 4 & 1.58 & 0.780 & 39.5 \\
\hline Wound & 5 & 2.46 & 0.947 & 49.2 \\
\hline Bleeding & 5 & 1.44 & 0.935 & 28.8 \\
\hline Burns & 4 & 2.21 & 0.820 & 55.25 \\
\hline Foreign body & 3 & 1.79 & 0.868 & 59.66 \\
\hline Poison & 4 & 2.80 & 1.024 & 70 \\
\hline Overall knowledge & 30 & 15.49 & 3.192 & 51.6 \\
\hline
\end{tabular}

The results showed that majority (62\%) of the samples had good knowledge, and (38\%) average knowledge about the first aid practice. Among the seven areas of the knowledge assessment on first aid measures the mean percentage score of the samples were highest (70\%) in the area of poisoning and lowest score $(28.8 \%)$ in the area of bleeding.

Section 3: Association between Knowledge with Selected Demographic Variables

\begin{tabular}{|c|c|c|c|c|c|c|}
\hline Variable & median(16) & $>$ median(16) & $\chi^{2}$ & Df & $\mathrm{p}$-value & $\chi^{2} \mathrm{tab}$ \\
\hline \multicolumn{7}{|l|}{ 1. Age } \\
\hline $25-30$ & 35 & 20 & 6.678 & 3 & 0.083 & 7.815 \\
\hline $31-40$ & 8 & 14 & & & $p>0.05$ & \\
\hline $41-50$ & 6 & 9 & & & NS & \\
\hline $51-60$ & 3 & 5 & & & & \\
\hline \multicolumn{7}{|l|}{ 2. Gender } \\
\hline Male & 12 & 24 & 7.853 & 1 & 0.005 & 3.841 \\
\hline Female & 40 & 24 & & & $P \varangle 0.05$ & \\
\hline \multicolumn{7}{|l|}{ 3. Educational status } \\
\hline Illiterate & 0 & 0 & 1.022 & 2 & 0.600 & 5.991 \\
\hline Primary & 28 & 24 & & & $p>0.05$ & \\
\hline High & 15 & 18 & & & NS & \\
\hline school & 9 & 6 & & & & \\
\hline \multicolumn{7}{|c|}{\begin{tabular}{l|l} 
Graduate & \\
\end{tabular}} \\
\hline \multicolumn{7}{|c|}{ 4. As a member of any social organization } \\
\hline Yes & 44 & 41 & 0.013 & 1 & 0.911 & 3.841 \\
\hline \multirow[t]{2}{*}{ No } & 8 & 7 & & & $p>0.05$ & \\
\hline & & & & & NS & \\
\hline \multicolumn{7}{|l|}{ 5. Occupation } \\
\hline Laborer & 26 & 18 & 7.243 & 3 & 0.065 & 7.815 \\
\hline $\begin{array}{l}\text { Private } \\
\end{array}$ & 13 & 24 & & & $p>0.05$ & \\
\hline Government & 3 & 1 & & & NS & \\
\hline Un employed & 10 & 5 & & & & \\
\hline \multicolumn{7}{|l|}{ 6. Place of living } \\
\hline Own house & 43 & 40 & 0.007 & 1 & 0.932 & 3.841 \\
\hline \multirow[t]{2}{*}{ Rental house } & 9 & 8 & & & $p>0.05$ & \\
\hline & & & & & NS & \\
\hline \multicolumn{7}{|l|}{ 7. Source of information } \\
\hline No source of information & 9 & 8 & 4.977 & 4 & 0.290 & 9.488 \\
\hline Friends & 6 & 7 & & & $p>0.05$ & \\
\hline Mass media & 7 & 13 & & & NS & \\
\hline Teaching program & 25 & 14 & & & & \\
\hline Health persons & 5 & 6 & & & & \\
\hline
\end{tabular}

\section{S=Significant, NS=Not Significant}

The table depicts that Since the Chi-square for the demographic variable like gender $\left(\chi^{2} \mathrm{cal}=7.853\right)$ the calculated value is greater than the table value $\left(\chi^{2} \operatorname{tab} 3.84\right)$ and also since the $p<0.05$ the research hypothesis is accepted because there is a significant association between the gender and first aid knowledge of self help group members. 


\section{Discussion :}

The study findings are consistent with the study conducted by Metin, C. M utlu in a total of 134 university students to find out their knowledge about first aid. The mean age of the students participating in research was found to be 20 $25 \mathrm{yrs}$ and $50 \%$ male, $50 \%$ female. It has been determined $65.7 \%$ students didn't get first aid knowledge before. M ost of the students $98.5 \%$ feel it is necessity to have first aid education. ${ }^{3}$

Another study conducted by De Silva W DAS et al among PHC workers in Sri Lanka. The PHC workers had an average knowledge score of $60 \%$ on first aid for poisoning. Among them, 78 (76\%) did not know the routes of entry of a poison into the body. None of them knew the appropriate first aid for swallowed poisons. Among the PHC workers, 58\% had not studied first aid at all. Those who had previous training in first aid in poisoning ( $42 \%$ ) had a higher knowledge score (70\%) compared to the scores of those who had no previous training. $84 \%$ of the PHC workers suggested having first aid for poisoning as a compulsory subject in

\section{Reference:}

1. Park K. Park's Text Book of Preventive and Social M edicine. $20^{\text {th }}$ Edition: Banaras and Bhanot Publication; 2009.

2. Prof. Dr. Nurhan Bayraktar. Evaluating the Effectiveness of a First Aid Training Course on Drivers. 2009 available from; http:// hacettepehemsirelikdergisi.org/pdf/pdf HHD 63.pdf.

3. Metin, C. M utlu. Level of knowledge about first aid of the University students. Trakia Journal of Sciences, Vol. 8, Suppl. 2, pp 262-265, 2010. available from http://www.uni-sz.bg

4. De Silva WDAS, Fernando R, Samarage SM . Knowledge, attitudes and skills among primary health care workers in sri lanka on first aid and safety for poisoning. Department of Forensic M edicine and Toxicology, University of Colombo, Sri Lanka.

5. Lavanya CH. A Quasi Experimental Study To Assess The Effectiveness Of Hands On Skill Training Programme CPR Among Adolescents In Selected Schools, Bangalore their basic training. ${ }^{4}$

The above study result were supported by a study conducted by $\mathrm{CH}$. Lavanya among adolescents about the CPR program the study result had revealed that there is no association between knowledge and selected demographic variables like age, gender, class studying, ordinal position, type of family, family income. ${ }^{5}$

\section{Conclusion:}

The findings of this study indicated the need for educating the self help group members about first aid practices. They must be motivated to adopt safety measures and practice first aid. There is a need of proper and regular educational programs to make awareness in the community about the importance of first aid practices.

There is a need for health personnel to take active part in education of the people regarding first aid. Many educational programs are successful in upgrading knowledge of layman during emergencies. 